Кириченко С.O.

Національній технічний університет Украӥні «КПІ»

\title{
ВИКОРИСТАННЯ СВІТОВОГО ДОСВІДУ ЗАДЛЯ РОЗВИТКУ СОЦІАЛЬНОЇ ІНФРАСТРУКТУРИ В РЕГІОНАХ УКРАЇНИ
}

\author{
ИСПОЛЬЗОВАНИЕ МИРОВОГО ОПЫТА ДЛЯ РАЗВИТИЯ СОЦИАЛЬНОЙ \\ ИНФРАСТРУКТУРЫ В РЕГИОНАХ УКРАИНЫ
}

\section{USING THE WORLD EXPERIENCE FOR DEVELOPING OF SOCIAL INFRASTRUCTURE IN THE REGIONS OF UKRAINE}

В статті досліджено світовий досвід розвитку сочіальної інфраструктури для використання його в межах регіонів Украӥни. Визначено, щуо розвиток інфраструктури, у тому числі сочіальної, розглядається багатьма країнами світу як платформа для їх майбутнього розвитку. Встановлено, що для розвитку сочіальної інфраструктури активно застосовується принции державно-приватного партнерства для більш активного залучення недержавних інвестиційних ресурсів. Це пов'язано з тим, щзо бюджетні витрати не можуть покривати зростаючи потреби у розвитку соціальної інфраструктури. 3'ясовано, на досягнення яких иілей спрямована існуюча взаємодія між державними органами влади та приватним бізнесом за рахунок системи сформованих взаємовідносин на основі державно-приватного партнерства. Проаналізовано досвід розвитку соиіальної інфраструктури за використанням держсавно-приватного партнерства у таких країнах, як: Канада, Італія, Великобританія, Австралія, Японія, Австрія, Аргентина, Німеччина, Франщія, Китай та інших. Доведено необхідність використання світового досвіду для розвитку соціальної інфраструктури в регіонах України. Обгрунтовано використання державно-приватного партнерства у формі концесійних проектів для зменшення бюджетних видатків, покращення якості соціальних послуг, залучення інвестиційних ресурсів, щзо дозволяє розподілити ризики між партнерами.

Ключові слова: розвиток, соціальна інфраструктура, світовий досвід, державноприватне партнерство, концесія

В статье исследован мировой опыт развития сочиальной инфраструктуры для использования его в регионах Украины. Определено, что развитие инфраструктуры, в том числе сочиальной, рассматривается многими странами мира как платформа для их будущего развития. Установлено, что для развития социальной инфраструктуры активно применяется принщип государственно-частного партнерства для более активного привлечения негосударственных инвестиционных ресурсов. Это связано с тем, что бюджетные расходы не могут покрывать растущие потребности в развитии социальной инфраструктуры. Определено, на достижение каких иелей направлено существующее взаимодействие между государственными органами власти и частным бизнесом за счет системы сложившихся взаимоотношений на основе государственно-частного партнерства. Проанализирован опыт развития сочииальной инфраструктуры с использованием государственно-частного партнерства в таких странах, как Канада, 
Италия, Великобритания, Австралия, Япония, Австрия, Аргентина, Германия, Франиия, Китай и другие. Доказана необходимость использования мирового опыта для развития соииальной инфраструктуры регионов Украиныл. Обосновано использование государственно-частного партнерства в форме концессионных проектов для уменьшения бюджетных расходов, улучшения качества сочиальных услуг, привлечения инвестиционных ресурсов, что позволяет распределить риски между партнерами.

Ключевые слова: развитие, социальная инфраструктура, мировой опыт, государственно-частное партнерство, концессия

The article is studied the world experience of social infrastructure for use by the regions of Ukraine. It been determined that the development of infrastructure, including social, considered by many countries as a platform for their future development. Determined that the development of social infrastructure is actively used the principle of public-private partnerships for greater involvement of private investment resources. This is related to the fact that the the budget costs can not covering the growing needs in the development of social infrastructure. It is determined to achieve the intended purpose of the existing cooperation between public authorities and private businesses at the expense of the existing system of relations based on public-private partnership. The experience is analyzed of the social infrastructure for the using of public-private partnerships in such countries as Canada, Italy, United Kingdom, Australia, Japan, Austria, Argentina, Germany, France, China and others. It is proved the necessity of using the experience for the development of social infrastructure in the regions of Ukraine. The application of public-private partnerships in the form of concession projects for reduction the budget expenditures, improve the quality of social services, attraction of investments, allowing you to allocate risks between the partners.

Key words: development, social infrastructure, global experience, public-private partnership, concession.

Вступ. Для розвитку соціальної інфраструктури в регіонах України, прийняття управлінських рішень щодо їі розвитку велике значення має дослідження світового досвіду, оскільки соціальна інфраструктура є одним 3 домінуючих факторів забезпечення задоволення різнопланових потреб людини а також розвитку регіонів. Сучасні умови економічної дестабілізації вимагають трансформації моделей управління та фінансування процесів розвитку соціальної інфраструктури та іiі об’єктів. Розвиток соціальної інфраструктури забезпечує доступність різнопланових життєвих благ населення, гарантії соціальної, екологічної безпеки, підвищення рівня та якості життя населення.

Починаючи 3 50-70-х років минулого століття відокремлення економічної категорії «інфраструктура» знайшло своє відображення у працях таких зарубіжних вчених: Р. Іохімсена, Х. Зінгера, Д. Кларка, А. Маршала, А. Пезенті, Д. Рея, П. Розенштейна-Родана, С. Симоніса, П. Самуельсона, А. Хіршмана, Г. Цехлина, С. Шотлера, А. Янгсона та ін. авторів.

Розв’язанню проблем розвитку соціальної інфраструктури присвячено роботи таких вітчизняних вчених як: О.М. Алимов, А.А. Багдаєв, Б.М. Данилишин, Є.Л. Логінов, А.А. Мазараки, М.К. Орлатий, Ю.І. Саенко, 
Д.М. Стеченко та ін. У роботах цих вчених досліджується сутність, класифікаційні ознаки та особливості функціонування соціальної інфраструктури. Незважаючи на велику кількість публікацій відносно функціонування соціальної інфраструктури, визначення ії сутності, проблем розвитку, управління та джерел іiі фінансування залишається й досі дискусійним та невирішеним завданням, у тому числі на регіональному рівні, що спонукає до дослідження світового досвіду, накопиченого у цієї сфері.

Постановка завдання. Метою статті $є$ дослідження світового досвіду розвитку соціальної інфраструктури для використання його в межах регіонів України. Для вирішення поставленої мети сформульовано такі завдання: дослідити механізми розвитку соціальної інфраструктури у різних країнах світу; обгрунтувати можливість використання світового досвіду для розвитку соціальної інфраструктури в регіонах України.

Методологія. Під час проведення дослідження було використано системний підхід, а також методи аналізу та синтезу - при вивчені досвіду розвитку соціальної інфраструктури окремих країн та групуванні результатів отриманого дослідження. Також застосовувався логічний метод та метод узагальнень для надання відповідних висновків та практичних рекомендацій щодо розвитку соціальної інфраструктури в регіонах України на основі проведеного аналізу світового досвіду.

Результати дослідження. За прогнозними даними найбільшої світової аудиторської та консалтингової компанії Price Waterhouse Coopers до 2025 року загальний обсяг інвестицій у інфраструктурні проекти перевищить 78 трлн. дол. У порівнянні, загальний обсяг світової економіки в 2013 , склав 87 трлн. дол. США. При цьому дві третини цієї суми припаде на країни Азіатсько-Тихоокеанського регіону. Економічна ефективність, на думку фахівців, може досягати $25 \%$ від інвестування в інфраструктурні проекти в енергетиці, транспортній інфраструктурі, комунальному господарстві, телекомунікаціях тощо [3]. Прогнозні дані щодо запланованого середньорічного обсягу інвестицій в інфраструктуру в період до 2020 року представлено на рисунку. У свою чергу, це вимагатиме збільшення обсягів фінансування з боку як державного та і приватного секторів. Небезпідставно розвиток соціальної інфраструктури багатьма країнами світу розглядається як платформа для майбутнього розвитку країни. 


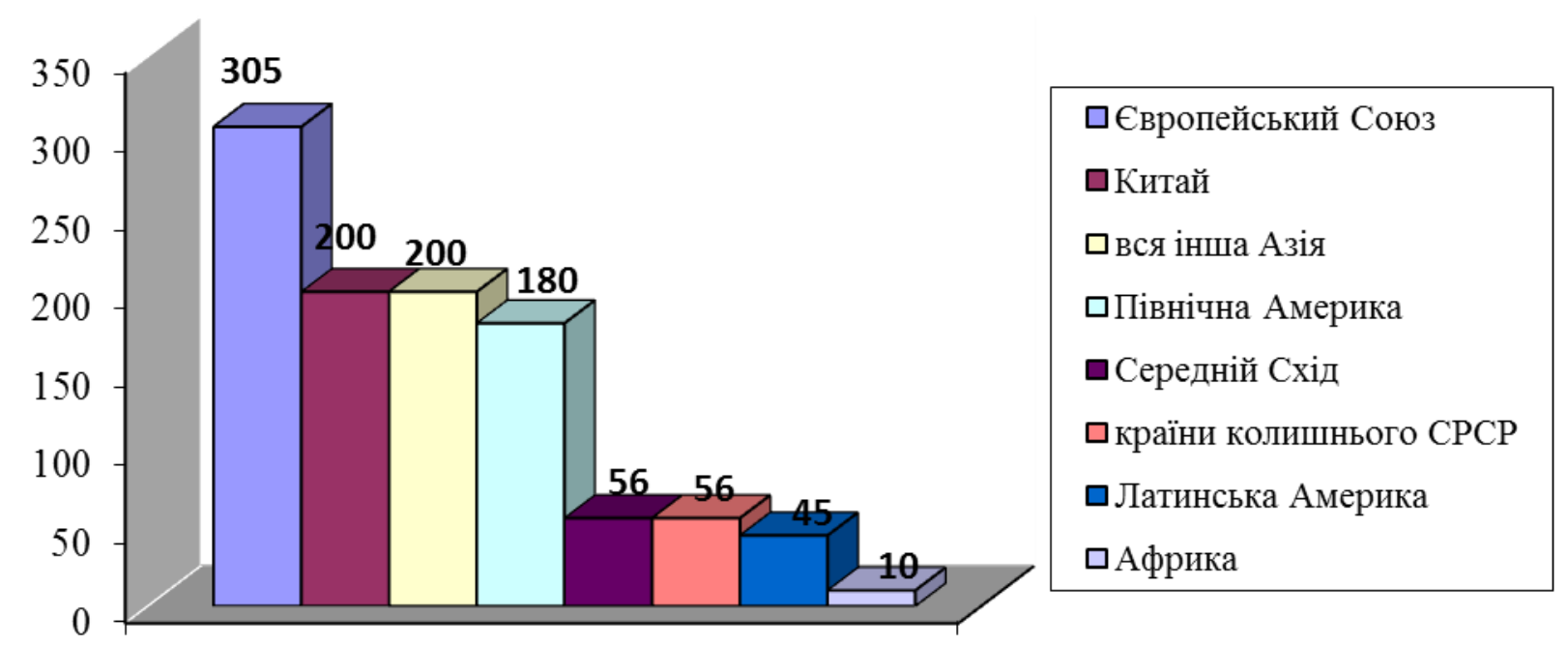

Рисунок. Прогнозні дані середньорічних обсягів інвестування в інфраструктурні проекти у період до 2020 року, млрд. дол. США [4]

За оцінками експертів інвестиції в інфраструктурні проекти у транспортному і телекомунікаційному секторах економіки на рівні $1 \%$ від обсягу ВНП національної економіки призводять до прискорення річних темпів зростання ВНП країни в розрахунку на душу населення на 0,6 \% [3]. Кожний мільярд доларів, інвестований у розвиток інфраструктури, створює безпосередньо 15 тис. робочих місць і приблизно 30 тис. додаткових робочих місць у суміжних з інфраструктурою галузях. Ефективність інвестування у розвиток соціальної інфраструктури може проявлятися через 25-30 років. На розвиток інфраструктури в розвинених країнах світу витрачається 6-8 \% від ВНП, у Китаї 8-10\% ВНП, Індії та Бразилії - 4-6\%, країнах Латинської Америки - 1-2 \% [4]. Все це доводить складність та багатогранність вимог до прийняття управлінських рішень щодо розвитку соціальної інфраструктури та iii об’єктів як на місцевому, так і на регіональному та державному рівнях.

Для розвитку соціальної інфраструктури активно застосовується принцип державно-приватного партнерства для більш активного залучення недержавних інвестиційних ресурсів. Це пов'язано перш за все 3 тим, що бюджетні витрати не можуть покривати зростаючи потреби у розвитку соціальної інфраструктури. За підрахунками McKinsey Global Institute до 2030 р. обсяг необхідних інвестицій на розвиток інфраструктури в світовому масштабі досягне 57 трлн. дол. США. Ця цифра більша за вартість всіх інфраструктурних об'єктів, побудованих на сьогоднішній час [12].

Так, наприклад, в Канаді створені корпорації економічного розвитку на основі державно-приватного партнерства, які безпосередньо займаються залученням інвестиційних ресурсів у розвиток соціальної інфраструктури $[10$, с. 52]. Ці корпорації створені поза підпорядкуванням муніципальної влади, 
але при цьому основне фінансування розвитку соціальної інфраструктури здійснюється саме за рахунок видатків муніципальних бюджетів. Головна роль таких корпорацій полягає у залученні грошей приватного бізнесу. Також такі корпорації мають горизонтальну організаційну структуру та спроможні швидко реагувати та вирішувати виниклі проблеми, а члени корпорації приймають активну участь в управлінні розвитком соціальної інфраструктури. Таким чином, управління та фінансування розвитку соціальної інфраструктури відбувається не тільки муніципальною владою, а й зовні 3 боку корпорацій. Також у Канаді для управління процесами державноприватного партнерства створено національний орган - Канадський фонд державно-приватного партнерства, який здійснює консалтингову, рекламну, методичну, координаційну діяльність, а також підтримку концесійних проектів розвитку соціальної інфраструктури. При цьому частка державних інвестицій у даних проектах не перевищує $25 \%$ [10, с. 88]. Одним із вагомих стимулів для приватних партнерів в Канаді $є$ те, що у законодавстві країни передбачено виплати у вигляді відрахувань відповідним одержувачам за участь їх у великих стратегічних інфраструктурних концесійних проектах, у тому числі соціальних, що сприяє підвищенню рівня життя в країні i/aбо іiі економічному зростанню. Це призвело до залучення приватних партнерів у концесійні угоди 3 реконструкції водоочисних станцій, побудови зон відпочинку, будівництва комплексів громадських споруд тощо.

Досвід Канади при залученні інвестиційних ресурсів приватного сектору для розвитку соціальної інфраструктури є неєдиним і далеко не першим. Так залучення приватних партнерів використовувалося ще у Римській імперії, коли передавали в управління приватним особам такі об'єкти інфраструктури як: поштові станції, порти, ринки та лазні. Основні принципи використання державно-приватного партнерства, які були закладені ще 3 тих часів збереглися і по наш час, але зазнали трансформацій під впливом економічних, політичних, соціальних змін та юридичних норм i правил. Використання державно-приватного партнерства для розвитку об'єктів соціальної інфраструктури широко використовується у світі у зв'язку 3 тим, що:

- ускладнюються і дорожчають суспільні завдання на тлі відносного зменшення необхідних фінансових ресурсів;

- виникає потреба у використанні управлінського досвіду приватного бізнесу та залученні ресурсів приватного сектора для виконання ряду функцій, які традиційно відносяться до завдань влади.

Існуюча взаємодія між державними органами влади та приватним бізнесом за рахунок системи сформованих взаємовідносин має на меті досягнення цілей двох груп: 
- по-перше, це врахування цілей та інтересів кожного з учасників взаємовідносин. Державні, муніципальні органи влади зацікавлені в реалізації соціально важливих проектів за рахунок відмови від неефективних форм господарювання і перекладання функцій управління належної йому власності на приватний сектор. Приватний партнер, який здійснює інвестиції, ставлячи на перший план отримання прибутку та економічну ефективність, зацікавлений у гарантованій, швидкій, якісній реалізації проекту, використовуючи державні гарантії, свої знання та досвід управління;

- по-друге, це спільно сформульовані цілі, безпосередньо пов'язані 3 конкретним проектом розвитку соціальної інфраструктури. Суспільство в підсумку отримує більш якісні товари та послуги при мінімальних витратах.

При використанні державно-приватного партнерства для розвитку соціальної інфраструктури перш за все мова йде про партнерство, що полягає у рівноправній участі сторін у реалізації довготермінових проектів у межах угод різних специфічних форм. Найбільш часто застосовується така форма державно-приватного партнерства як концесія. Сам термін «концесія» походить від лат. concessio (дозвіл, поступка) і в загальному випадку означає договір між бізнесом і державою, що фіксує умови використання приватним партнером державної власності. У США концесія використовувалась у XVII ст., коли прибуваючим 3 інших країн на поселення громадянам губернатори штатів видавали концесію на землю, річки та будівництво доріг [1111]. У Свропі концесійні угоди у сфері міського господарства набули поширення на початку XIX ст. Так у Франції у 1882 було укладено концесію на 15 років між муніципальною владою та братами Перрье, які зобов'язалися постачати воду в Париж. Це призвело до того, що сьогодні близько $70 \%$ населення міста забезпечує водою приватний бізнес на умовах концесії. Але, необхідно наголосити, що це були далеко не перші концесійні угоди у Франції. Наприклад, ще у 1554 році була підписана концесія на будівництво каналу між урядом та Адамом де Крапоном. Ейфелева вежа також побудована за використання концесії [6].

Необхідно відзначити, що досвід використання концесії був i y Радянському Союзі за часів проведення нової економічної політики (НЕП) у 1922-1927 рр. Концесійні угоди оформлювалися у вигляді двостороннього договору, який надавав дозвіл на здійснення певної діяльності та визначав права й обов'язки концесіонера. Концесіонером могла бути юридична особа у вигляді або промислового, торговельного, або торгово-промислового підприємства, у тому числі у формі акціонерного товариства. До влади за період НЕПу надійшло біля 2 тисяч концесійних пропозицій від німецьких, французьких, американських, англійських компаній, з яких було реалізовано близько $10 \%$ [2, с. 35]. Концесійні проекти використовувалися у обробній, добувній й важкій промисловості, сільському господарстві, в галузі 
електропостачання та залізничному будівництві. Використання концесії сприяло розвитку промисловості, частковому оновленню застарілої техніки на виробництві, зростанню продуктивності праці, збільшенню державних надходжень від оподаткування, збільшенню зайнятості населення. У той же час, для приватних іноземних інвесторів концесії давали доступ до видобутку дефіцитної сировини, до гарантованого ринку збуту, і дозволяли отримувати прибуток, який перевищував середньогалузевий. Але після проведення політики НЕПу з переходом до командно-адміністративної економіки від концесійної форми залучення іноземного капіталу повністю відмовилися.

У 1923 у Італіїбув підписаний перший закон про концесію, яку активно використовують для розвитку об'єктів соціальної інфраструктури. Всі концесійні проекти в соціальній інфраструктурі Італії спрямовані на зниження витрат державного сектору. Концесійні угоди стали можливими практично в будь-якому секторі суспільних послуг після юридичної реформи 1998 року. Найбільша кількість концесій в Італії у транспортній галузі та в галузі охорони здоров'я.Концесія як форма державно-приватного партнерства знайшла використання більше ніж у 120 країнах світу. За даними Міжнародного Банку реконструкції та розвитку концесія використовується у $66 \%$ укладання контрактів між державними органами влади і приватними партнерами у сфері транспортної інфраструктури в країнах, що розвиваються та країнах з перехідною економікою. У 82-х таких країнах світу за десятиліття 32000 р. до 2010 р. у транспортну інфраструктуру було залучено 253,2 млрд. дол. США у межах 1190 проектів, з яких 53 \% - це концесійні угоди [5].

Яскравим прикладом країни, де використовується концесія для розвитку виробничої та соціальної інфраструктури є Великобританія. У 1992 році там було проголошено нову концепцію управління державною власністю «Приватна фінансова ініціатива» (Private Finance Initiative), що полягала у передачі приватному бізнесу в рамках концесії функцій фінансування будівництва, експлуатації, реконструкції, управління державних об'єктів соціальної інфраструктури, а також в таких галузях соціальної інфраструктури як охорона здоров'я, освіта та підвищення кваліфікації робочої сили тощо [15]. При цьому було розроблено нормативно-правові акти про місцеве самоврядування за якими муніципальні органи як корпорації можуть приймати участь в якості юридичних осіб у концесіях із забезпеченням їх автономності у рамках відповідних повноважень. Перевірку фінансових витрат на розвиток соціальної інфраструктури у тому числі за рахунок державно-приватного партнерства здійснює три органи:

- по-перше, створене Національне бюро аудиту (The National Audit Office) за контролем реалізації концесійних проектів, яке проводить аудит ефективності витрачених державних інвестицій на розвиток соціальної інфраструктури для Парламенту; 
- по-друге, Комітет 3 державного бюджету здійснює перевірки фінансових потоків для Палати громад;

- по-третє, Департамент великих інфраструктурних проектів здійснює контроль за державними інвестиціями та якістю наданих населенню соціальних послуг, а також забезпечує координацію дій усіх суб'єктів управління процесом розвитку соціальної інфраструктури.

Результатом дії створеної у Великобританії системи державноприватного партнерства, iii нормативно-законодавчого порядку та контролю стало отримання позитивних результатів як для населення так і для держави. $91 \%$ опитаних респондентів у Великобританії задоволені якістю отриманих соціальних послуг [1515]. За даними Національного бюро аудиту щорічна економія державних коштів на фінансування соціальної сфери становить від 2 до 3 млрд. фунтів стерлінгів [14]. Впродовж 2001-2008 pр. у Великобританії було підписано 536 концесійних проектів на суму 61 млрд. фунтів стерлінгів. У порівнянні, у цей же період в Європі було укладено 215 концесійних проектів на суму 37 млрд. фунтів [14].

Отже, у Великобританії за рахунок того, що держава виступає надійним партнером приватного бізнесу, ретельно контролюючі свої фінансові потоки, які направлені у довгострокові концесійні контракти, та залучаючи інвестиції приватного сектору, досягнуто вагомих позитивних результатів у розвитку соціальної інфраструктури, наданні якісних соціальних послуг.

В Австралії для розвитку соціальної інфраструктури також активно задіяне державно-приватне партнерство, де Міністерством інфраструктури $\mathrm{i}$ транспорту створена Робоча група фінансування та розвитку соціальної інфраструктури, що включає представників Уряду, громадських об'єднань, банківського сектору, пенсійних фондів тощо. Завдяки плідній співпраці приватного сектора, регіональних та державних органів влади, у розвиток соціальної інфраструктури окрім державних субсидій фінансування було залучено інвестиції приватних партнерів, що сприяло зниженню витрат приватних інвесторів, пов'язаних 3 проведенням торгів за концесійними угодами, усуненню адміністративних бар'єрів при залучені інвестицій [1616]. Концесійні проекти розвитку соціальної інфраструктури в Австралії частіше всього реалізуються на основі федеральних програм. Наприклад, за механізмом концесії було побудовано високошвидкісну трасу «East Link» на основі тендеру на 39 років, після чого вона переходить у власність Уряду. Концесіонер «Connect East» здійснював фінансування будівництва, організацію планувальних, конструкторських і ремонтних робіт, введення траси в експлуатацію. Концесія була частиною федеральної програми та супроводжувалася консультативною та інформативною підтримкою з боку Консультаційної Ради штату Вікторія. Координацією проекту і встановленням екологічних стандартів займалася Адміністрація м. Мельбурн. Інтереси 
федерального Уряду представляло Transport Department of East and West Australian (Управління транспортом Сходу і Заходу Австраліі).

На регіональному рівні відбувається залучення приватних інвестицій у розвиток соціальної інфраструктури в Японії. Для цього Урядом у 2006 році було змінено нормативно-правову базу у напряму надання суспільних послуг та механізму державно-приватного партнерства. У результаті чого було створено систему так званого «ринкового тестування» для сприяння переведенню на ринкову основу частини суспільних послуг, суб'єктами надання яких традиційно були організації бюджетної сфери, підпорядковані Уряду або муніципальній владі. Цікавим досвідом є концесійні проекти по створенню парків відпочинку та спеціальних районів із формуванням в них відповідної соціальної інфраструктури. Так у Токіо за підтримкою Бюро міського розвитку були здійснені концесійні проекти у межах благоустрою міста по створенню парків відпочинку відкритих для всіх жителів міста [1]. Приватному партнеру дозволено на території парку створювати будь-які об’єкти дозвілля у тому числі комерційні. Концесійні угоди по будівництву таких парків затверджує Губернатор Токіо за поданням Токійського Уряду. Також в Токіо набуло розвитку створення спеціальних районів по формуванню в них відповідної соціальної інфраструктури для певних соціальних груп, а саме молодих сімей з дітьми. У таких районах розвиток соціальної інфраструктури орієнтований на задоволення потреб, в першу чергу, сімей 3 дітьми та спрямований на забезпечення дитячими майданчиками, дитячими садами, школами тощо. Практика довела високий комерційний попит на нерухомість в даних районах серед відповідних категорій населення за рахунок локальної спеціалізації соціальної інфраструктури.

Отже, за рахунок активної співпраці регіональної влади 3 приватними організаціями, часткового фінансування Уряду, додаткових стимулів для приватного партнеру у вигляді пільгових умов довгострокової оренди та податкових пільг, концесійні проекти розвитку соціальної інфраструктури в Японії набули свого поширення.

Важливим є врахування досвіду використання концесії в Австрії щодо забезпечення доступності та якості соціальних послуг, насамперед, для соціально вразливих груп населення. В Австрії надання соціальних послуг $€$ обов'язком держави 3 розмежуванням федеральних i регіональних повноважень. Там діє такий механізм: наприклад, приватна соціальна організація «Соціальний фонд Відня» надає соціальні послуги від імені магістрату Відня; при цьому фонд на конкурсній основі розміщує замовлення на соціальні послуги між приватними, комерційними й некомерційними організаціями, допомагає клієнтам зробити вибір, здійснює необхідні доплати, 
перераховуючи кошти безпосередньо обраній клієнтом організації, контролює дотримання узгоджених умов надання соціальних послуг [8, с. 94].

Світовий досвід доводить ще одну позитивну рису використання концесії при розвитку соціальної інфраструктури, а саме не тільки покращення якості соціальних послуг, а й зниження їх вартості. Так в Аргентині, у Буенос-Айресі використання концесії строком на 30 років у водопостачанні та каналізації дозволило не тільки знизити обсяг державних інвестицій, поліпшити роботу всієї системи водопостачання та каналізації, збільшити кількість споживачів, а й знизити тарифи на споживання води та водовідведення. На $26 \%$ було знижено тарифи на воду у Колумбії в м. Монтеррей за рахунок передачі у концесійне управління системи водопостачання і каналізації іспанському консорціуму FCC [7]. У Німеччині було знижено тарифи на електропостачання завдяки концесійним угодам між муніципалітетами та власниками комунальних підприємств. Приватні партнери при цьому приймаються у відповідне комунальне підприємство як пайовики, які вносять майновий внесок у спільне підприємство [9]. У Франції при збереженні державної власності у електроенергетиці, тепло-, газопостачанні за рахунок концесії строком на 40-75 років були віддані генеруючи потужності та постачання електроенергії споживачам, що також позитивно відбилось на тарифах для споживачів. Концесії на постачання електроенергії видаються Радою префектур, узгоджуються з комунами, департаментом і центральним Урядом.

Позитивний досвід використання концесії строком на 25-30 років також мають такі країни як Австралія, Болгарія, Чехія, Португалія, Угорщина, Польща, Філіппіни, Чилі, окремі міста у США, в результаті чого були знижені тарифи на різні житлово-комунальні послуги.

Хотілось би ще наголосити на соціально-орієнтованому досвіді Німеччини - 24 концесійні проекти 356 спрямовані в освіту. Яскравим прикладом поєднання направленості розвитку освіти та охорони здоров'я $\epsilon$ концесійний проект «Франкфуртський інноваційний центр біотехнологій» (Frankfurter Innovations zentrum Biotechnologie $\mathrm{GmbH}$ ), учасниками партнерства якого виступає Уряд федеральної землі Гессен, муніципалітет м. Франкфурта-на-Майні, Промислово-торгова палата .. Франкфурта-наМайні. Центр спеціалізується на дослідженнях білка та на захворюваннях центральної нервової системи, запальних захворюваннях. Він об'єднує 11 фармацевтичних компаній, інформаційно-технологічні компанії та Центр дослідження, розробки та забезпечення безпеки ліків при Університеті Іоганна Гете (м. Франкфурт-на-Майні) [8, с. 63].

За даними Світового банку Китаю щорічно на розвиток соціальної інфраструктури необхідно інвестувати 130 млрд. дол. США, а загальний обсяг витрат держави на соціальну сферу становить 200 млрд. дол. США за рік, що 
становить 40 \% доходів державного бюджету. Такі витрати спонукали владу КНР у 2004 році внести зміни до Конституції щодо націоналізації земель та дозволили використання концесії при реалізації великомасштабних проектів розвитку інфраструктури переважно у будівництві доріг і швидкісних магістралей, мостів, навчальних закладів тощо. Це дало можливість залучити приватні інвестиції та розпочати широкомасштабні проекти. Так за концесійним проектом на 300 млрд. дол. США до 2020 року планується побудувати 16 тис. км. нової швидкісної залізниці, що також має сприяти збільшенню зайнятості населення у будівництві. На будівництві гілки Шанхай - Пекін залучено 100 тис. працівників, за проектом планується побудувати 42 високошвидкісні гілки [13].

У Китаї отримали розвиток концесійні проекти при будівництві водоканалів та електростанцій, автомобільних доріг, нових ліній метрополітену та легкого метро, створення ліній швидкісного автобусу, що зв'язує житлові квартали міст 3 промисловими і комерційними центрами. Прикладами таких концесійних проектів є: будівництво електростанції Лейбін Бі Пауер Плент (Laibin B Power Plant) в провінції Гуангчі - у концесії на тендерній основі приймали участь іноземні інвестори; будівництво водоочисних станції в Ченду, Шеньянг та Пекіні. У 2005 році в Пекіні було створено суспільний експертно-аналітичний відділ «Китайській центр державно-приватного партнерства» (China Center for Public-Private Partnerships), який займається аналітичними дослідженнями та контролем за концесійними проектами у сфері комунальних послуг [8, с. 61]. За досить незначний час при налагодженні взаємовигідних відносин між державою, приватними партнерами та громадськістю за використання різних форм державно-приватного партнерства, у тому числі концесії, були отримані суттєві позитивні результати у соціальній сфері Китайської Народної Республіки.

Необхідно відзначити роль міжнародних фінансових інститутів, таких як Світовий банк, СБРР, які мають вагому роль при підтримці концесійних проектів розвитку соціальної інфраструктури за умов використання концесійних форм партнерства, особливо в країнах Латинської Америки та Східної Азії. При цьому кожна міжнародна фінансова організація має свої вимоги щодо отримання інвестиційних ресурсів на розвиток соціальної інфраструктури. У тому числі визначається реальність проекту, розраховуються економічні показники внутрішньої норми повернення та чистої приведеної вартості, а також гарантоване повернення фінансових ресурсів з відповідним прибутком тощо. Також для отримання інвестиційних ресурсів у широкомасштабні концесійні проекти можуть залучатися декілька міжнародних фінансових організацій за умов вигідності концесійних проектів для кожного з учасників та обов'язковій умові місцевого співфінансування. 
Висновки. До елементів наукової новизни даного дослідження відноситься узагальнення світового досвіду розвитку соціальної інфраструктури на основі системного підходу у різних країнах світу, що дало можливість обгрунтувати дієвий ефективний механізм практичної реалізації використання державно-приватного партнерства, а саме у формі концесії. Використання концесії забезпечує розвиток соціальної інфраструктури, що сприяє задоволенню духовних та матеріальних потреб, досягненню більш високого рівня життя, забезпеченню соціальної захищеності населення. Умови залучення приватних партнерів закріплюються у законодавчо-правових нормах країн, кожна з яких має свої особливості, але загальними рисами є те, що вони враховують інтереси як суспільства в цілому, так і різних соціальних груп і верств населення та кожної окремої людини.

Отже, проведене дослідження розвитку соціальної інфраструктури в різних країнах світу доводить, що не існує універсальної стратегії ії розвитку та управління. Кожна країна має свій підхід та механізми розвитку соціальної інфраструктури вибір яких залежить від пріоритетів держави, ії економічного стану й фінансових можливостей тощо. Але світовий досвід численних країн світу доводить необхідність використання державно-приватного партнерства для розвитку соціальної інфраструктури в різних його формах, у тому числі у формі концесії, оскільки виникає зростаючий розрив між фінансовими бюджетними можливостями та вимогами суспільства до соціальної інфраструктури та соціальних послуг, а особливо із урахуванням збільшення масштабів й вартості інфраструктурних об’єктів.

Багато країн мають величезний досвід використання концесії для розвитку соціальної інфраструктури та відповідну нормативно-правову базу i механізми взаємодії державної, муніципальної влади, приватних партнерів та громадськості. Оскільки соціальна інфраструктура призначена для задоволення загальних умов діяльності людини, впливає на відтворювальний потенціал країни та розвиток іiі регіонів, то незалежно від форми контролю над iï складовими та об'єктами, державним чи приватним походженням інвестиційних ресурсів, інфраструктурні проекти повинні максимально задовольняти суспільні потреби, що допомагає забезпечити державний нагляд над проектуванням, фінансуванням, будівництвом, функціонуванням i ремонтом інфраструктурних об'єктів.

Використання концесії широко застосовується у проектах будівництва та експлуатації об’єктів транспортної інфраструктури та житловокомунальних комплексах, a також у освіті, підвищенні кваліфікації працівників, медицині тощо. Тобто концесійні проекти використовуються не тільки у будівництві соціальної інфраструктури, а й у наданні приватним партнером відповідних соціальних послуг населенню. Концесія дозволяє залучити інвестиції приватного сектору у розвиток соціальної інфраструктури, 
знизити витрати державного та місцевих бюджетів, розподілити ризики між партнерами та задовольнити споживачів якісними послугами. Викликає зацікавленість досвід щодо забудови територій за використанням концесійних проектів, соціальна інфраструктура яких спрямована на певні потреби конкретних соціальних верств населення.

Практичне значення результатів дослідження полягає у застосуванні світового досвіду щодо розвитку соціальної інфраструктури в регіонах України, у залученні ресурсів місцевих бюджетів, цільових державних асигнувань, а також ресурсів приватного бізнесу за рахунок державноприватного партнерства. Позитивні риси світового досвіду, на нашу думку, можуть бути успішно використані для розвитку соціальної інфраструктури в регіонах України.

Подальші наукові розробки за даним напрямом дослідження полягають у розробці пропозицій 3 удосконалення нормативно-правової бази та створення спеціальних інститутів 3 регулювання партнерських відносин у вигляді: асоціацій, проектних та керуючих компаній, державних корпорацій, агентств із залучення інвестицій, національних агентств з розвитку територій, страхових компанії тощо.

\section{Література:}

1. Глазко Н. Д. Зарубіжний досвід забезпечення соціальної сфери / Н. Д. Глазко // Ефективна економіка : наукове фахове видання: [Електронний ресурс]. - 2014. - №5. Режим доступу до журналу : http://www.economy.nayka.com.ua

2. Иностранные инвестиции в СССР (1920-1930рр.) [Текст] / Загорулько М. М., Булатов В. В., Вихор А. П. и др. - М. : Современная экономика и право, 2005. - 856 с.

3. Инфраструктура как фактор роста / Свобода слова : [Електронний ресурс]. - Режим доступу : http://www.svoboda.org/content/article/25432479.html

4. Кондратьев В. Инфраструктура как фактор экономического роста / В. Кондратьев // Сетевое издание Центра исследований и аналитики Фонда исторической перспективы. [Електронний ресурс]. http://www.perspektivy.info/rus/ekob/infrastruktura_kak_faktor_ekonomicheskogo_rosta_20 10-11-10.htm

5. Концесія як форма державно-приватного партнерства // Державне агентство автомобільних доріг в Україні [Електронний ресурс]. - Режим доступу : http://www.ukravtodor.gov.ua/zapitannya-ta-vidpovidi-1/\%D1\%81_1-2.html

6. Курмаєв П. Ю. Дослідження зарубіжного досвіду управління соціально-економічним розвитком на регіональному рівні / П. Ю. Курмаєв. [Електронний ресурс] - Режим доступу : nbuv.gov.ua/kpr/2009_25/kurmaev.htm

7. Свистунов Н. Концессии - инструмент активизации международных инвестиционных проектов [Текст] / Н. Свистунов // Проблемы теории и практики управления, 2004. №3. - С. 75-80.

8. Сідуняк О. В. Зарубіжний досвід використання державно-приватного партнерства у соціальній сфері [Текст] / О. В. Сідуняк // Світове господарство і міжнародні економічні відносини : зб. наук. пр. Вип. ІІ (54), 2014. - С. 58-67. 
9. Социально-ориентированное местное управление: опыт городов Германии [Текст] / Под ред. Б. М. Гринчеля, Н. Е. Костылевой. - СПб. : Наука, 1999. - 338 с.

10. Стратегическое планирование экономического развития: 35 лет канадского опыта [Текст] // науч. ред. Б. С. Жихаревич. - СПб. : Международный центр социальноэкономических исследований «Леонтьевский центр», 2004. - 288 с.

11. Супян В. Б. Американская экономика: новые реальности и приоритеты XXI века [Текст] / В. Б.Супян. - М.: «Анкил», 2001. - 138 с.

12. Infrastructure productivity: How to save $\$ 1$ trillion a year / McKinsey Global Institute. 2013. - January. - P. 1.

13. International Union of Railways. 2009. Infrastructure 2010. Investment Imperative. Urban Land Institute and Ernst \& Young, Wash. D.C. 2010.

14. Lessons from PFI and other projects [Електронний ресурс]. - Режим доступу : http://www.nao.org.uk/lessons-from-pfi-and-other-projects

15. Private Finance Initiative: meeting the investment challenge [Електронний ресурс]. Режим доступу: http://www.hmtreasury.gov.uk

16. Release of the Infrastructure Finance and Funding Reform / Australia Government. Department of infrastructure and Transport : [Електронний ресурс]. - Режим доступу : http://www.infrastructure.gov.au/infrastructure/ 